\title{
New practice in semaglutide on type-2 diabetes and obesity: clinical evidence and expectation
}

\author{
Yalin Liu, Xianghang Luo (凶) \\ Department of Endocrinology, Endocrinology Research Center, Xiangya Hospital of Central South University, Changsha 410008, China; \\ National Clinical Research Center for Geriatric Disorders, Xiangya Hospital of Central South University, Changsha 410008, China \\ (C) Higher Education Press 2022
}

\begin{abstract}
Obesity is an important risk factor of type 2 diabetes (T2D), which has become an important factor threatening human health. However, no perfect drug choice for obesity exists. Semaglutide is a kind of human glucagon-like peptide-1 (GLP-1) analog that promotes insulin secretion while inhibiting glucagon secretion through a glucose concentration-dependent mechanism. GLP-1 can also delay stomach emptying and suppress appetite to help lose weight. This review summarizes clinical evidence of the semaglutide effect on T2D and obesity and establishes expectations on future clinical trials for obesity treatment.
\end{abstract}

Keywords semaglutide; type 2 diabetes; obesity

\section{Introduction}

With the improvement of people's living standards in recent years, diabetes has become an important factor threatening human health. The International Diabetes Federation statistics in 2019 showed that approximately 463 million adults aged $20-79$ years in the world were suffering from diabetes, indicating that 1 in 11 people had diabetes. Another estimate is that the number of diabetic patients will reach 578.4 million by 2030 , and the number may reach 700.2 million by 2045 [1]. Diabetes is a kind of metabolic disease characterized by high blood sugar and is often characterized by polydipsia, polyphagia, polyuria, and weight loss. Moreover, long-term hyperglycemia causes chronic damage and dysfunction of various tissues, especially eyes [2], kidneys [3], heart [4], blood vessels [5], and nerves [6]. Meanwhile, obesity is a chronic disease that requires long-term treatment $[7,8]$, and approximately 650 million people suffer from obesity worldwide [9]. Obesity is a recognized risk factor for ischemic heart disease, atherosclerosis, and stroke [10]. Furthermore, it can lead to common chronic diseases such as chronic kidney disease, hypertension, and type-2 diabetes (T2D) [11]. Nowadays, a range of restrictive measures limiting the spread of coronavirus disease 2019 (COVID-19) may

Received March 12, 2021; accepted May 29, 2021

Correspondence: Xianghang Luo, xianghangluo@hotmail.com have a negative impact on weight-management practices, and a high body mass index has also been identified as a risk factor for COVID-19 mortality [12-14].

Obesity and T2D are closely correlated. People with abnormal glucose metabolism often have dyslipidemia, hypertension, hyperuricemia, fatty liver, and obesity, and insulin resistance is the common cause of these abnormalities. Obesity is regarded as an important cause of T2D. As the condition progresses, many obese patients are bound to evolve to the stage of clinical T2D, and a series of complications will soon occur. Therefore, the development of efficient weight-loss drugs is imminent. However, no perfect drug choice exists for obesity. Complex medication regimens $[15,16]$ and subsequent adverse events may further affect patient compliance.

Glucagon-like peptide-1 (GLP-1) is an intestinal hormone secreted by the L cells of the small intestine after eating stimulation [17]. GLP-1 receptors are primarily distributed in the pancreas, intestine, and central nervous system. GLP-1 receptor agonists can enhance insulin secretion caused by increased glucose and inhibit glucagon secretion. In detail, glucose plays a major role in regulating insulin secretion. When extracellular glucose levels rise, pancreatic $\beta$ cells allow glucose entry via glucose transporter-2 [18]. This phenomenon elevates intracellular ATP $[19,20]$, thereby promoting the closure of ATPsensitive potassium channels [21]. Furthermore, changes in cell-membrane potential and voltage-dependent $\mathrm{Ca}^{2+}$ channel activation lead to $\mathrm{Ca}^{2+}$ flowing in from outside the 
cell, which then promotes exocytosis and insulin secretion. GLP-1-mediated insulin secretion can be observed only at elevated glucose concentration. GLP-1 analogs produce more cAMP by binding to GLP-1 receptor on pancreatic $\beta$ cells [19] and subsequently enhance glucose activity by further increasing the permeability of $\mathrm{Ca}^{2+}$ channels, thereby enabling more $\mathrm{Ca}^{2+}$ influx to increase insulin release [22]. It can also delay stomach emptying [23] and suppress appetite [24] (Fig. 1; created using material in Servier Medical Art under CC BY 3.0 license). Some GLP-1 receptor agonists such as liraglutide, exenatide, and efpeglenatide [25] have been marketed and used to treat obese patients, and their efficacy is shown in Table 1 . Furthermore, GLP-1 receptor agonist such as liraglutide provides better and longer glycemic control with a lower risk of hypoglycemia in individualized treatment of T2D patients. It showed as well an advantage in reducing major cardiovascular adverse events and mortality compared with other treatment regimens [26]. In general, GLP-1 receptor agonists are extensively used in the treatment of obesity and T2D. However, their efficacy and usage mode can still be improved. Semaglutide is a kind of human GLP-1 analog that promotes insulin secretion while inhibiting glucagon secretion through a glucose concentration-dependent mechanism. Notably, the risk of hypoglycemia is not high [27].

\section{Clinical evidence of the effect of subcutaneous semaglutide on T2D}

T2D is a complex disease with different factors affecting blood-sugar control. Many people still cannot reach the recommended blood-glucose concentration [28] despite wide-ranging treatment options [15]. Moreover, complex medication regimens $[15,16]$, subsequent adverse events, medication-induced weight gain, and possible risk of hypoglycemia [29] may affect patient compliance and further hinder the achievement of blood-glucose goals. Semaglutide Unabated Sustainability in Treatment of Type 2 Diabetes (SUSTAIN) is a series of phase-3 clinical trials that comprehensively evaluate the efficacy, safety, cardiovascular, and renal adverse events, as well as other outcomes, of subcutaneous semaglutide in the T2D population.

Among them, SUSTAIN 1-5 [30-34] and SUSTAIN 7-10 [35-38] compare semaglutide with placebo and active control drugs in a randomized and double-blind trial population, with the efficacy and safety of semaglutide as the main research endpoints. The results after 30-56 weeks show that semaglutide performs significantly better in reducing $\mathrm{HbA}_{1 \mathrm{c}}$ than other controls, including placebo, sitagliptin, insulin glargine, canagliflozin, dulaglutide, liraglutide, and exenatide extended release. The proportion of patients with $\mathrm{HbA}_{1 \mathrm{c}}<7 \%$ or $\leqslant 6.5 \%$ in the semaglutide group is significantly higher than that in the other controls. As high as $80 \%$ of patients in the semaglutide 1.0 $\mathrm{mg}$ group could achieve the standard rate of $\mathrm{HbA}_{1 \mathrm{c}}$ $\left(\mathrm{HbA}_{1 \mathrm{c}}<7 \%\right)$, with the highest reaching $1.8 \%$. Additionally, the weight-loss effect of semaglutide is better than those of the others, with the semaglutide $1.0 \mathrm{mg}$ group losing weight up to $6.5 \mathrm{~kg}$. In terms of safety, semaglutide has a similar incidence rate of adverse events to other controls, among which the most common adverse events

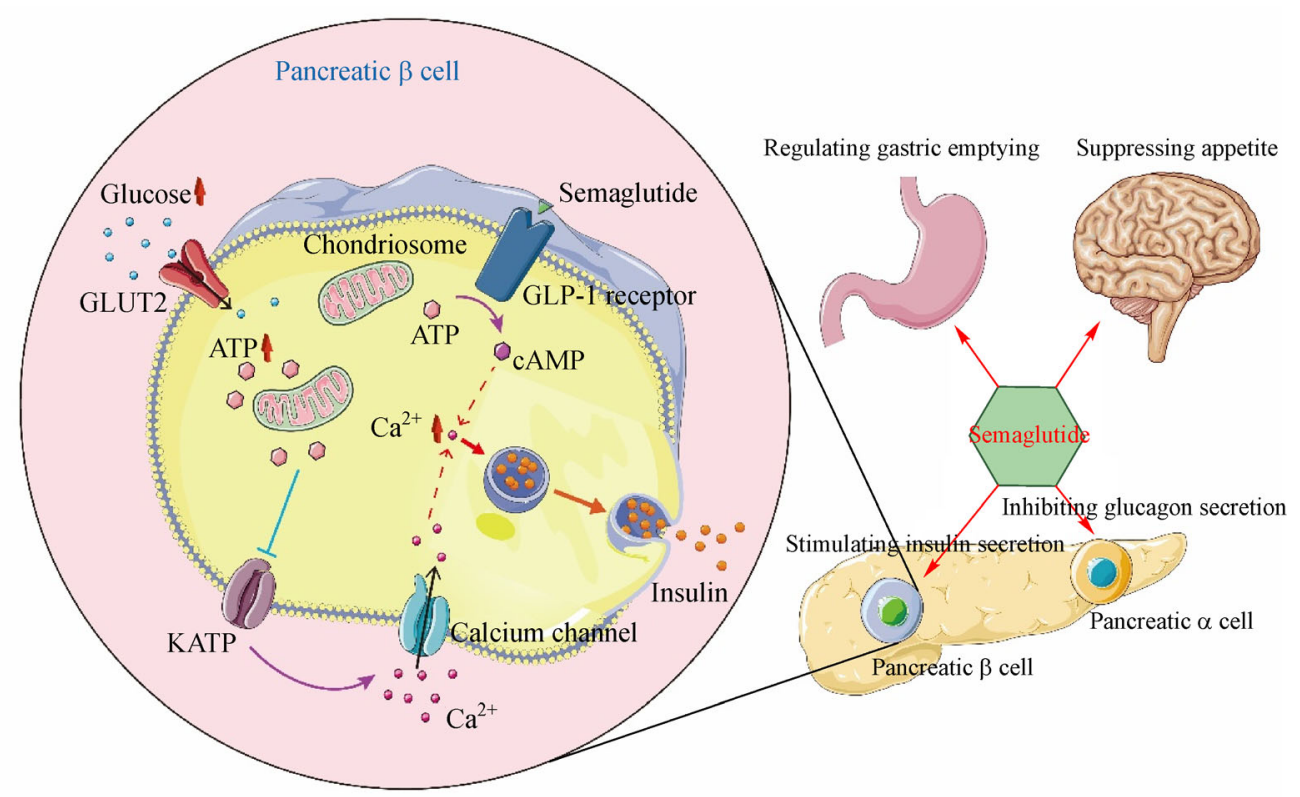

Fig. 1 Regulatory mechanism of semaglutide. 


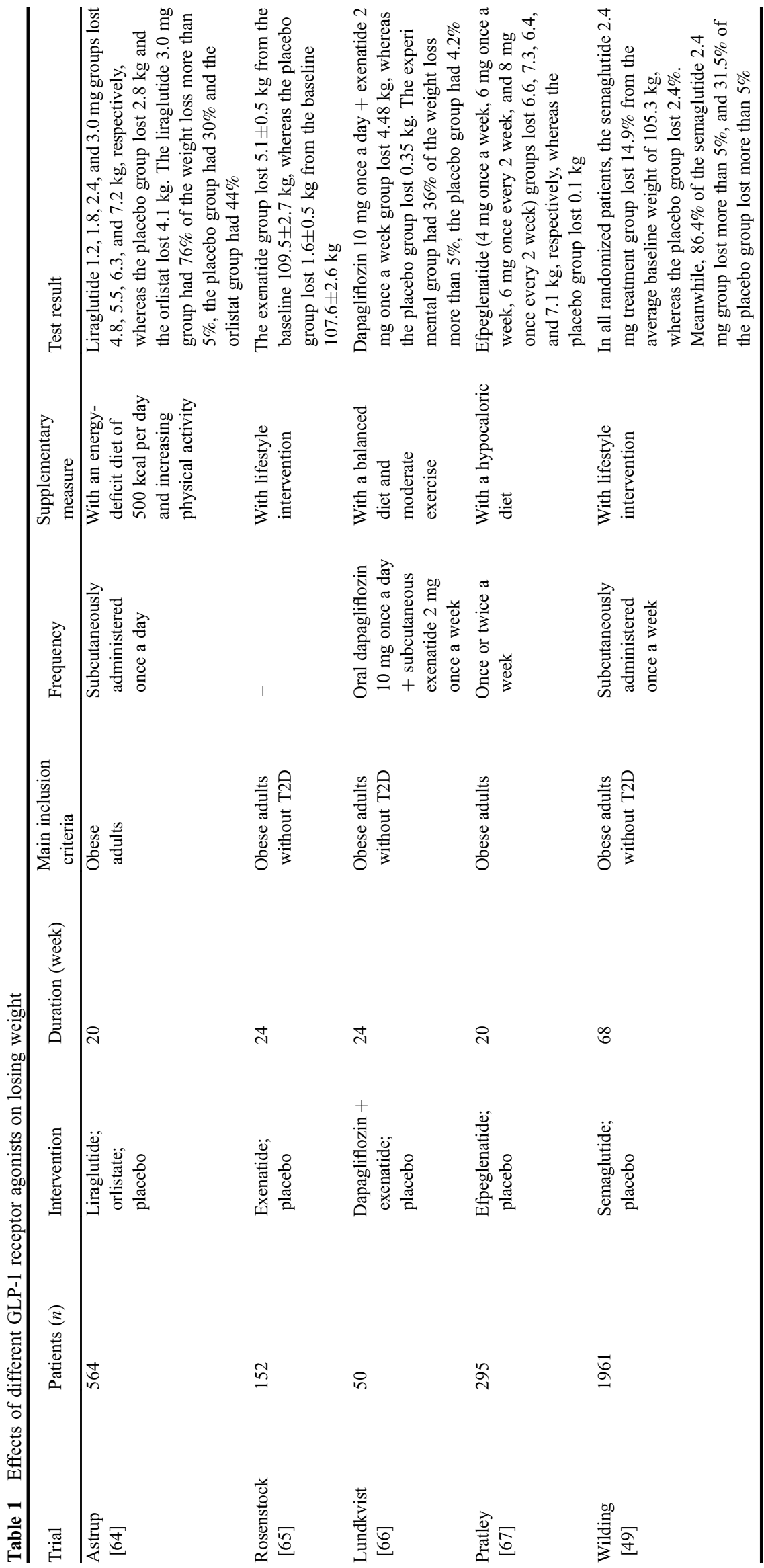


are gastrointestinal adverse events. Mild to moderate and transient nausea are the most common gastrointestinal adverse events of semaglutide. In early December 2017, a once-a-week subcutaneous injection of semaglutide was approved by the US FDA and marketed under the brand name Ozempic.

\section{Clinical evidence of the effect of oral semaglutide on T2D}

Oral GLP-1 receptor agonist can be used in early-stage $\mathrm{T} 2 \mathrm{D}$ and is more acceptable to T2D patients. Oral dosage forms need to overcome various challenges, including extremely low oral bioavailability, limited gastrointestinal epithelial penetration, degradation under proteolytic enzymes, and low $\mathrm{pH}$ environment in the stomach. Oral semaglutide is the first GLP-1 receptor agonist for oral administration. To study its efficacy, safety, and adverse reactions, 10 phase- 3 clinical trials of Peptide InnOvatioN for Early DiabEtes TReatment (PIONEER) series have been performed, covering a wide range of people with T2D [39-48]. An analysis of all 9543 patients with T2D who had or had not been treated with insulin has shown that oral semaglutide is effective in improving blood-sugar control across various baseline blood-glucose levels. Compared with all control groups, 7 and $14 \mathrm{mg}$ doses of semaglutide could significantly reduce $\mathrm{HbA}_{1 \mathrm{c}}$. Furthermore, the safety of oral semaglutide is consistent with that of other GLP-1 receptor agonist drugs, similar to that of subcutaneous semaglutide. In the PIONEER $1-5,7$, and 8 studies, the proportion of T2D patients who reach the $\mathrm{HbA}_{1 \mathrm{c}}<7 \%$ target in the oral semaglutide 7 and $14 \mathrm{mg}$ groups is higher than that in the control groups. This finding indicates that oral semaglutide may help T2D patients who have uncontrolled blood-sugar levels to improve their condition.

\section{Clinical evidence of the effects of subcutaneous semaglutide on obesity and future expectations}

In a newly published article, a double-blind randomized controlled trial was conducted by Wilding et al. [49], recruiting 1961 obese or overweight adults without diabetes. Accompanied with lifestyle interventions, semagluide $2.4 \mathrm{mg}$ or placebo was subcutaneously injected once a week. Results showed that among obese or overweight participants, semaglutide $2.4 \mathrm{mg}$ once a week plus lifestyle interventions correlated with sustained, clinically significant weight loss (Fig. 2). In all randomized patients, the semaglutide $2.4 \mathrm{mg}$ treatment group lost $14.9 \%$ from the average baseline weight of $105.3 \mathrm{~kg}$, whereas the placebo group lost $2.4 \%$. Additionally, $86.4 \%$ of the semaglutide $2.4 \mathrm{mg}$ group lost more than $5 \%$, and $31.5 \%$ of the placebo group lost more than $5 \%$. For the trial product estimand, the semaglutide $2.4 \mathrm{mg}$ treatment group lost $16.9 \%$ of the body weight, whereas the placebo group lost $2.4 \%$. The semaglutide $2.4 \mathrm{mg}$ group had $92.4 \%$ of the weight loss $\geqslant 5 \%$, and the placebo group had $33.1 \%$. Among patients receiving semaglutide, the most common adverse event is gastrointestinal. Most effects are transitory and only mild to moderate.

Semagluide is a good choice for weight loss, and its once-a-week dosing method greatly improves compliance.
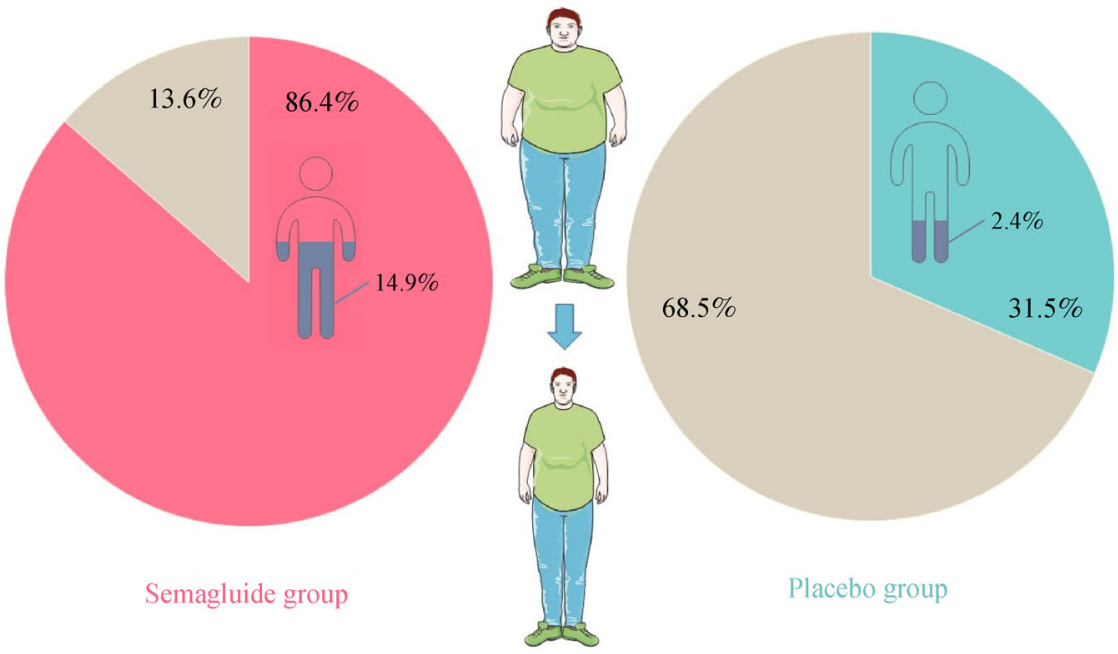

Fig. 2 In the research of Wilding et al. [49], people in the semaglutide $2.4 \mathrm{mg}$ treatment group lost $14.9 \%$ weight from the average baseline weight of $105.3 \mathrm{~kg}$, whereas those in the placebo group lost $2.4 \%$. Meanwhile, $86.4 \%$ of people in the semaglutide $2.4 \mathrm{mg}$ group lost $\geqslant 5 \%$ weight, and $31.5 \%$ of those in the placebo group lost more than $5 \%$. 
However, compared with oral administration, injection administration still has certain operational difficulties. In that case, the dosage form of semaglutide and the corresponding weight-loss effect can further be explored in the future. Other GLP-1 receptor agonists such as liraglutide also have weight-loss effects [50] (Table 1), but these are not as obvious as those of semaglutide. Among them, liraglutide needs to be subcutaneously administered once a day, and these GLP-1 receptor agonists can lead to weight loss of only up to $7.3 \mathrm{~kg}$, whereas semaglutide 2.4 $\mathrm{mg}$ can lead to an average weight loss of $15 \mathrm{~kg}$. However, due to different research objects and different experimental designs, the exact corresponding effects compared with semaglutide are not easy to obtain. Thus, trials can also be designed to compare the weight-loss effects of semaglutide and other weight-losing products.

Lifestyle intervention is not clearly defined in the study of Wilding et al. [49], and it has a considerable influence on weight loss $[51,52]$. From this point of view, whether the results of complementary lifestyle interventions exaggerate the effects of semaglutide remains to be discussed. Furthermore, whether weight rebound occurs after semaglutide withdrawal, resulting in significant weight gain or drug dependence, can also be studied. Notably, the methodology of studies evaluating gastrointestinal symptoms is primarily through self-report rather than the use of available validated gastrointestinal symptom questionnaires.

Obesity is a significant risk factor for cardiovascular disease and related complications that significantly increase the risk of death [53,54]. Individuals with abdominal obesity are at increased risk of angina, heart failure, myocardial infarction, and atrial fibrillation [55]. As an auxiliary means of lifestyle intervention, the use of antiobesity medications can improve the risk factors of cardiovascular disease [56,57] and usually exert a beneficial effect on certain cardiometabolic parameters [58]. Studies have shown that the children of mothers exposed to metformin have lower central hemodynamics and diastolic index than those exposed to placebo. These results suggest that the use of metformin in obese pregnant women may have beneficial cardiovascular effects on their offspring [59]. However, some reports have reflected poor cardiovascular outcomes after the application of weightloss drugs [60,61]. Aminorex can result in pulmonary hypertension; fenfluramine and dexfenfluramine may result in cardiac valvulopathy; and sibutramine may lead to myocardial infarction. After the withdrawal of sibutramine from the market due to its life-threatening side effects, the FDA sought for cardiovascular safety data on new antiobesity medications [62]. Therefore, continuous monitoring of antiobesity products for any potential safety issue is important [63]. Nevertheless, a once-a-week subcutaneous injection of semaglutide $2.4 \mathrm{mg}$ is still proven to play a crucial role in improving the condition of obese or overweight people, with only mild to moderate gastrointestinal adverse reactions. Overall, semaglutide has great potential and value in various diseases and may benefit many more patients in the near future through a few more studies in obese or overweight people.

\section{Conclusions}

Obesity is closely correlated with T2D, which brings about many complications. Semaglutide is a kind of human GLP1 analog that has undergone a series of clinical trials for obesity and T2D treatment. However, its effects on cardiovascular disease when treating obese people require further study.

\section{Compliance with ethics guidelines}

Yalin Liu and Xianghang Luo declare that they have no conflict of interest. This manuscript is a review article and does not involve a research protocol requiring approval by the relevant institutional review board or ethics committee.

\section{References}

1. Diabetes Atlas IDF. 2019. https://diabetesatlas.org/en/ (accessed March 1, 2021)

2. Potilinski MC, Lorenc V, Perisset S, Gallo JE. Mechanisms behind retinal ganglion cell loss in diabetes and therapeutic approach. Int J Mol Sci 2020; 21(7): E2351

3. Catrina SB, Zheng X. Hypoxia and hypoxia-inducible factors in diabetes and its complications. Diabetologia 2021; 64(4): 709-716

4. Tadic M, Grassi G, Cuspidi C. Cardiorespiratory fitness in patients with type 2 diabetes: a missing piece of the puzzle. Heart Fail Rev 2021; 26(2): 301-308

5. La Sala L, Prattichizzo F, Ceriello A. The link between diabetes and atherosclerosis. Eur J Prev Cardiol 2019; 26(2_suppl): 15-24

6. Shieh JC, Huang PT, Lin YF. Alzheimer's disease and diabetes: insulin signaling as the bridge linking two pathologies. Mol Neurobiol 2020; 57(4): 1966-1977

7. Garvey WT, Mechanick JI, Brett EM, Garber AJ, Hurley DL, Jastreboff AM, Nadolsky K, Pessah-Pollack R, Plodkowski R; Reviewers of the AACE/ACE Obesity Clinical Practice Guidelines. American Association of Clinical Endocrinologists and American College of Endocrinology Comprehensive Clinical Practice Guidelines for Medical Care of Patients with Obesity. Endocr Pract 2016; 22(Suppl 3): 1-203

8. Yumuk V, Tsigos C, Fried M, Schindler K, Busetto L, Micic D, Toplak H; Obesity Management Task Force of the European Association for the Study of Obesity. European guidelines for obesity management in adults. Obes Facts 2015; 8(6): 402-424

9. World Health Organization. Obesity and overweight. 2018. https:// www.who.int/en/news-room/fact-sheets/detail/obesity-and-overweight (accessed March 1, 2021)

10. Lyon MR, Kacinik V. Is there a place for dietary fiber supplements in weight management? Curr Obes Rep 2012; 1(2): 59-67 
11. Heymsfield SB, Wadden TA. Mechanisms, pathophysiology, and management of obesity. N Engl J Med 2017; 376(3): 254-266

12. Klang E, Kassim G, Soffer S, Freeman R, Levin MA, Reich DL. Severe obesity as an independent risk factor for COVID-19 mortality in hospitalized patients younger than 50 . Obesity (Silver Spring) 2020; 28(9): 1595-1599

13. Cefalu WT, Rodgers GP. COVID-19 and metabolic diseases: a heightened awareness of health inequities and a renewed focus for research priorities. Cell Metab 2021; 33(3): 473-478

14. Drucker DJ. Diabetes, obesity, metabolism, and SARS-CoV-2 infection: the end of the beginning. Cell Metab 2021; 33(3): 479498

15. Inzucchi SE, Bergenstal RM, Buse JB, Diamant M, Ferrannini E, Nauck M, Peters AL, Tsapas A, Wender R, Matthews DR. Management of hyperglycemia in type 2 diabetes, 2015: a patientcentered approach: update to a position statement of the American Diabetes Association and the European Association for the Study of Diabetes. Diabetes Care 2015; 38(1): 140-149

16. Nau DP. Recommendations for improving adherence to type 2 diabetes mellitus therapy - focus on optimizing oral and non-insulin therapies. Am J Manag Care 2012; 18(3 Suppl): S49-S54

17. Gasbjerg LS, Bergmann NC, Stensen S, Christensen MB, Rosenkilde MM, Holst JJ, Nauck M, Knop FK. Evaluation of the incretin effect in humans using GIP and GLP-1 receptor antagonists. Peptides 2020; 125: 170183

18. Leturque A, Brot-Laroche E, Le Gall M. GLUT2 mutations, translocation, and receptor function in diet sugar managing. Am J Physiol Endocrinol Metab 2009; 296(5): E985-E992

19. Doyle ME, Egan JM. Mechanisms of action of glucagon-like peptide 1 in the pancreas. Pharmacol Ther 2007; 113(3): 546-593

20. De Vos A, Heimberg H, Quartier E, Huypens P, Bouwens L, Pipeleers D, Schuit F. Human and rat beta cells differ in glucose transporter but not in glucokinase gene expression. J Clin Invest 1995; 96(5): 2489-2495

21. Gromada J, Brock B, Schmitz O, Rorsman P. Glucagon-like peptide-1: regulation of insulin secretion and therapeutic potential. Basic Clin Pharmacol Toxicol 2004; 95(6): 252-262

22. MacDonald PE, Wheeler MB. Voltage-dependent $\mathrm{K}^{+}$channels in pancreatic beta cells: role, regulation and potential as therapeutic targets. Diabetologia 2003; 46(8): 1046-1062

23. Hjerpsted JB, Flint A, Brooks A, Axelsen MB, Kvist T, Blundell J. Semaglutide improves postprandial glucose and lipid metabolism, and delays first-hour gastric emptying in subjects with obesity. Diabetes Obes Metab 2018; 20(3): 610-619

24. Song Y, Koehler JA, Baggio LL, Powers AC, Sandoval DA, Drucker DJ. Gut-proglucagon-derived peptides are essential for regulating glucose homeostasis in mice. Cell Metab 2019; 30(5): 976-986.e3

25. Aroda VR. A review of GLP-1 receptor agonists: evolution and advancement, through the lens of randomised controlled trials. Diabetes Obes Metab 2018; 20(Suppl 1): 22-33

26. Orsini Federici M, Gentilella R, Corcos A, Torre E, Genovese S. Changing the approach to type 2 diabetes treatment: a comparison of glucagon-like peptide-1 receptor agonists and sulphonylureas across the continuum of care. Diabetes Metab Res Rev 2021; [Epub ahead of print] doi: 10.1002/dmrr.3434

27. Meloni AR, DeYoung MB, Lowe C, Parkes DG. GLP-1 receptor activated insulin secretion from pancreatic $\beta$-cells: mechanism and glucose dependence. Diabetes Obes Metab 2013; 15(1): 15-27

28. Stark Casagrande S, Fradkin JE, Saydah SH, Rust KF, Cowie CC. The prevalence of meeting A1C, blood pressure, and LDL goals among people with diabetes, 1988-2010. Diabetes Care 2013; 36 (8): 2271-2279

29. Van Gaal L, Scheen A. Weight management in type 2 diabetes: current and emerging approaches to treatment. Diabetes Care 2015; 38(6): 1161-1172

30. Sorli C, Harashima SI, Tsoukas GM, Unger J, Karsbøl JD, Hansen T, Bain SC. Efficacy and safety of once-weekly semaglutide monotherapy versus placebo in patients with type 2 diabetes (SUSTAIN 1): a double-blind, randomised, placebo-controlled, parallel-group, multinational, multicentre phase 3a trial. Lancet Diabetes Endocrinol 2017; 5(4): 251-260

31. Ahrén B, Masmiquel L, Kumar H, Sargin M, Karsbøl JD, Jacobsen SH, Chow F. Efficacy and safety of once-weekly semaglutide versus once-daily sitagliptin as an add-on to metformin, thiazolidinediones, or both, in patients with type 2 diabetes (SUSTAIN 2): a 56-week, double-blind, phase 3a, randomised trial. Lancet Diabetes Endocrinol 2017; 5(5): 341-354

32. Ahmann AJ, Capehorn M, Charpentier G, Dotta F, Henkel E, Lingvay I, Holst AG, Annett MP, Aroda VR. Efficacy and safety of once-weekly semaglutide versus exenatide ER in subjects with type 2 diabetes (SUSTAIN 3): a 56-week, open-label, randomized clinical trial. Diabetes Care 2018; 41(2): 258-266

33. Aroda VR, Bain SC, Cariou B, Piletič M, Rose L, Axelsen M, Rowe E, DeVries JH. Efficacy and safety of once-weekly semaglutide versus once-daily insulin glargine as add-on to metformin (with or without sulfonylureas) in insulin-naive patients with type 2 diabetes (SUSTAIN 4): a randomised, open-label, parallel-group, multicentre, multinational, phase $3 \mathrm{a}$ trial. Lancet Diabetes Endocrinol 2017; 5(5): 355-366

34. Rodbard HW, Lingvay I, Reed J, de la Rosa R, Rose L, Sugimoto D, Araki E, Chu PL, Wijayasinghe N, Norwood P. Semaglutide added to basal insulin in type 2 diabetes (SUSTAIN 5): a randomized, controlled trial. J Clin Endocrinol Metab 2018; 103(6): 2291-2301

35. Pratley RE, Aroda VR, Lingvay I, Lüdemann J, Andreassen C, Navarria A, Viljoen A; SUSTAIN 7 investigators. Semaglutide versus dulaglutide once weekly in patients with type 2 diabetes (SUSTAIN 7): a randomised, open-label, phase 3b trial. Lancet Diabetes Endocrinol 2018; 6(4): 275-286

36. Lingvay I, Catarig AM, Frias JP, Kumar H, Lausvig NL, le Roux CW, Thielke D, Viljoen A, McCrimmon RJ. Efficacy and safety of once-weekly semaglutide versus daily canagliflozin as add-on to metformin in patients with type 2 diabetes (SUSTAIN 8): a doubleblind, phase 3b, randomised controlled trial. Lancet Diabetes Endocrinol 2019; 7(11): 834-844

37. Zinman B, Bhosekar V, Busch R, Holst I, Ludvik B, Thielke D, Thrasher J, Woo V, Philis-Tsimikas A. Semaglutide once weekly as add-on to SGLT-2 inhibitor therapy in type 2 diabetes (SUSTAIN 9): a randomised, placebo-controlled trial. Lancet Diabetes Endocrinol 2019; 7(5): 356-367

38. Capehorn MS, Catarig AM, Furberg JK, Janez A, Price HC, Tadayon S, Vergès B, Marre M. Efficacy and safety of once-weekly semaglutide $1.0 \mathrm{mg}$ vs once-daily liraglutide $1.2 \mathrm{mg}$ as add-on to 1-3 oral antidiabetic drugs in subjects with type 2 diabetes 
(SUSTAIN 10). Diabetes Metab 2020; 46(2): 100-109

39. Aroda VR, Rosenstock J, Terauchi Y, Altuntas Y, Lalic NM, Morales Villegas EC, Jeppesen OK, Christiansen E, Hertz CL, Haluzík M; PIONEER 1 Investigators.. PIONEER 1: randomized clinical trial of the efficacy and safety of oral semaglutide monotherapy in comparison with placebo in patients with type 2 diabetes. Diabetes Care 2019; 42(9): 1724-1732

40. Rodbard HW, Rosenstock J, Canani LH, Deerochanawong C, Gumprecht J, Lindberg SØ, Lingvay I, Søndergaard AL, Treppendahl MB, Montanya E; PIONEER 2 Investigators. Oral semaglutide versus empagliflozin in patients with type 2 diabetes uncontrolled on metformin: the PIONEER 2 trial. Diabetes Care 2019; 42(12): 2272-2281

41. Rosenstock J, Allison D, Birkenfeld AL, Blicher TM, Deenadayalan S, Jacobsen JB, Serusclat P, Violante R, Watada H, Davies M; PIONEER 3 Investigators. Effect of additional oral semaglutide vs sitagliptin on glycated hemoglobin in adults with type 2 diabetes uncontrolled with metformin alone or with sulfonylurea: the PIONEER 3 randomized clinical trial. JAMA 2019; 321(15): $1466-1480$

42. Pratley R, Amod A, Hoff ST, Kadowaki T, Lingvay I, Nauck M, Pedersen KB, Saugstrup T, Meier JJ; PIONEER 4 investigators. Oral semaglutide versus subcutaneous liraglutide and placebo in type 2 diabetes (PIONEER 4): a randomised, double-blind, phase 3a trial. Lancet 2019; 394(10192): 39-50

43. Mosenzon O, Blicher TM, Rosenlund S, Eriksson JW, Heller S, Hels OH, Pratley R, Sathyapalan T, Desouza C; PIONEER 5 Investigators. Efficacy and safety of oral semaglutide in patients with type 2 diabetes and moderate renal impairment (PIONEER 5): a placebo-controlled, randomised, phase 3a trial. Lancet Diabetes Endocrinol 2019; 7(7): 515-527

44. Bain SC, Mosenzon O, Arechavaleta R, Bogdański P, Comlekci A, Consoli A, Deerochanawong C, Dungan K, Faingold MC, Farkouh ME, Franco DR, Gram J, Guja C, Joshi P, Malek R, Merino-Torres JF, Nauck MA, Pedersen SD, Sheu WH, Silver RJ, Tack CJ, Tandon N, Jeppesen OK, Strange M, Thomsen M, Husain M. Cardiovascular safety of oral semaglutide in patients with type 2 diabetes: rationale, design and patient baseline characteristics for the PIONEER 6 trial. Diabetes Obes Metab 2019; 21(3): 499-508

45. Pieber TR, Bode B, Mertens A, Cho YM, Christiansen E, Hertz CL, Wallenstein SOR, Buse JB, Akın S, Aladağ N, Arif AA, Aronne LJ, Aronoff S, Ataoglu E, Baik SH, Bays H, Beckett PL, Berker D, Bilz S, Bode B, Braun EW, Buse JB; PIONEER 7 investigators. Efficacy and safety of oral semaglutide with flexible dose adjustment versus sitagliptin in type 2 diabetes (PIONEER 7): a multicentre, openlabel, randomised, phase 3a trial. Lancet Diabetes Endocrinol 2019; 7(7): 528-539

46. Zinman B, Aroda VR, Buse JB, Cariou B, Harris SB, Hoff ST, Pedersen KB, Tarp-Johansen MJ, Araki E; PIONEER 8 Investigators. Efficacy, safety, and tolerability of oral semaglutide versus placebo added to insulin with or without metformin in patients with type 2 diabetes: the PIONEER 8 trial. Diabetes Care 2019; 42(12): 2262-2271

47. Yamada Y, Katagiri H, Hamamoto Y, Deenadayalan S, Navarria A, Nishijima K, Seino Y; PIONEER 9 investigators. Dose-response, efficacy, and safety of oral semaglutide monotherapy in Japanese patients with type 2 diabetes (PIONEER 9): a 52-week, phase 2/3a, randomised, controlled trial. Lancet Diabetes Endocrinol 2020; 8(5):
377-391

48. Yabe D, Nakamura J, Kaneto H, Deenadayalan S, Navarria A, Gislum M, Inagaki N; PIONEER 10 Investigators. Safety and efficacy of oral semaglutide versus dulaglutide in Japanese patients with type 2 diabetes (PIONEER 10): an open-label, randomised, active-controlled, phase 3a trial. Lancet Diabetes Endocrinol 2020; 8(5): 392-406

49. Wilding JPH, Batterham RL, Calanna S, Davies M, Van Gaal LF, Lingvay I, McGowan BM, Rosenstock J, Tran MTD, Wadden TA, Wharton S, Yokote K, Zeuthen N, Kushner RF. Once-weekly semaglutide in adults with overweight or obesity. N Engl J Med 2021; 384(11): 989-1002

50. Whicher CA, Price HC, Phiri P, Rathod S, Barnard-Kelly K, Ngianga K, Thorne K, Asher C, Peveler RC, McCarthy J, Holt RIG. The use of liraglutide $3.0 \mathrm{mg}$ daily in the management of overweight and obesity in people with schizophrenia, schizoaffective disorder and first episode psychosis: results of a pilot randomized, doubleblind, placebo-controlled trial. Diabetes Obes Metab 2021; 23(6): 1262-1271

51. Cienfuegos S, Gabel K, Kalam F, Ezpeleta M, Wiseman E, Pavlou V, Lin S, Oliveira ML, Varady KA. Effects of 4- and 6-h timerestricted feeding on weight and cardiometabolic health: a randomized controlled trial in adults with obesity. Cell Metab 2020; 32(3): 366-378.e3

52. Wilkinson MJ, Manoogian ENC, Zadourian A, Lo H, Fakhouri S, Shoghi A, Wang X, Fleischer JG, Navlakha S, Panda S, Taub PR. Ten-hour time-restricted eating reduces weight, blood pressure, and atherogenic lipids in patients with metabolic syndrome. Cell Metab 2020; 31(1): 92-104.e5

53. Mavrogeni SI, Bacopoulou F, Markousis-Mavrogenis G, Chrousos G, Charmandari E. Cardiovascular imaging in obesity. Nutrients 2021; 13(3): 744

54. Zhang X, Zhang Y, Wang P, Zhang SY, Dong Y, Zeng G, Yan Y, Sun L, Wu Q, Liu H, Liu B, Kong W, Wang X, Jiang C. Adipocyte hypoxia-inducible factor $2 \alpha$ suppresses atherosclerosis by promoting adipose ceramide catabolism. Cell Metab 2019; 30(5): 937-951. e5

55. Itoh H, Kaneko H, Kiriyama H, Kamon T, Fujiu K, Morita K, Michihata N, Jo T, Takeda N, Morita H, Yasunaga H, Komuro I. Metabolically healthy obesity and the risk of cardiovascular disease in the general population - analysis of a nationwide epidemiological database. Circ J 2021; 85(6): 914-920

56. Van Gaal L, Pi-Sunyer X, Després JP, McCarthy C, Scheen A. Efficacy and safety of rimonabant for improvement of multiple cardiometabolic risk factors in overweight/obese patients: pooled 1year data from the Rimonabant in Obesity (RIO) program. Diabetes Care 2008; 31(Suppl 2): S229-S240

57. Mahú I, Barateiro A, Rial-Pensado E, Martinéz-Sánchez N, Vaz SH, Cal PMSD, Jenkins B, Rodrigues T, Cordeiro C, Costa MF, Mendes R, Seixas E, Pereira MMA, Kubasova N, Gres V, Morris I, Temporão C, Olivares M, Sanz Y, Koulman A, Corzana F, Sebastião AM, López M, Bernardes GJL, Domingos AI. Brain-sparing sympathofacilitators mitigate obesity without adverse cardiovascular effects. Cell Metab 2020; 31(6): 1120-1135.e7

58. Chao AM, Wadden TA, Berkowitz RI, Quigley K, Silvestry F. The risk of cardiovascular complications with current obesity drugs. Expert Opin Drug Saf 2020; 19(9): 1095-1104

59. Panagiotopoulou O, Syngelaki A, Georgiopoulos G, Simpson J, 
Akolekar R, Shehata H, Nicolaides K, Charakida M. Metformin use in obese mothers is associated with improved cardiovascular profile in the offspring. Am J Obstet Gynecol 2020; 223(2): 246.e1-246. e10

60. Federal Register. FDA withdrawal of fen-phen. 2015. https://www. govinfo.gov/content/pkg/FR-2015-09-29/pdf/2015-24619.pdf (accessed March 1, 2021)

61. Medscape. FDA announces sibutramine has been withdrawn from the market. 2010. https://www.medscape.org/viewarticle/730515 (accessed March 1, 2021)

62. Colman E, Golden J, Roberts M, Egan A, Weaver J, Rosebraugh C. The FDA's assessment of two drugs for chronic weight management. N Engl J Med 2012; 367(17): 1577-1579

63. Rodgers RJ, Tschöp MH, Wilding JP. Anti-obesity drugs: past, present and future. Dis Model Mech 2012; 5(5): 621-626

64. Astrup A, Rössner S, Van Gaal L, Rissanen A, Niskanen L, Al Hakim M, Madsen J, Rasmussen MF, Lean ME; NN8022-1807 Study Group. Effects of liraglutide in the treatment of obesity: a randomised, double-blind, placebo-controlled study. Lancet 2009; 374(9701): 1606-1616

65. Rosenstock J, Klaff LJ, Schwartz S, Northrup J, Holcombe JH, Wilhelm K, Trautmann M. Effects of exenatide and lifestyle modification on body weight and glucose tolerance in obese subjects with and without pre-diabetes. Diabetes Care 2010; 33(6): 11731175

66. Lundkvist P, Sjöström CD, Amini S, Pereira MJ, Johnsson E, Eriksson JW. Dapagliflozin once-daily and exenatide once-weekly dual therapy: a 24-week randomized, placebo-controlled, phase II study examining effects on body weight and prediabetes in obese adults without diabetes. Diabetes Obes Metab 2017; 19(1): 49-60

67. Pratley RE, Kang J, Trautmann ME, Hompesch M, Han O, Stewart J, Sorli $\mathrm{CH}$, Jacob S, Yoon KH. Body weight management and safety with efpeglenatide in adults without diabetes: a phase II randomized study. Diabetes Obes Metab 2019; 21(11): 24292439 